\title{
IDENTIFICATION OF ARCHITECTURAL FUNCTIONS IN A FOUR-DIMENSIONAL SPACE
}

\author{
Firza Utama; Daryanto \\ Architecture Department, Faculty of Engineering, Binus University \\ Jln. K.H. Syahdan No. 9, Palmerah, Jakarta Barat 11480 \\ firza.utama@binus.ac.id; daryanto@binus.edu
}

\begin{abstract}
This research has explored the possibilities and concept of architectural space in a virtual environment. The virtual environment exists as a different concept, and challenges the constraints of the physical world. One of the possibilities in a virtual environment is that it is able to extend the spatial dimension higher than the physical three-dimension. To take the advantage of this possibility, this research has applied some geometrical four-dimensional (4D) methods to define virtual architectural space. The spatial characteristics of $4 D$ space is established by analyzing the four-dimensional structure that can be comprehended by human participant for its spatial quality, and by developing a system to control the fourth axis of movement. Multiple three-dimensional spaces that fluidly change their volume have been defined as one of the possibilities of virtual architectural space concept in order to enrich our understanding of virtual spatial experience.
\end{abstract}

Keywords: virtual architecture, four-dimensional space, controller system

\begin{abstract}
ABSTRAK
Penelitian ini memperlihatkan kemungkinan untuk menerapkan konsep ruang arsitektural dalam lingkungan maya. Lingkungan maya memiliki sifat yang berbeda dan bertentangan dengan ruang fisik, salah satunya adalah kemungkinan untuk membangun ruang dengan dimensi geometri melebihi tiga dimensi (3D). Penelitian ini memanfaatkan geometri empat dimensi (4D) untuk mendefinisikan ruang arsitektur dalam lingkungan maya. Karakteristik ruang $4 D$ didapatkan dari penganalisaan struktur dari ruang $4 D$ yang dapat dimengerti oleh pengguna ruang berdasarkan dari kualitas spasial dengan membangun sistim untuk mengontrol sumbu ke-4 dari ruang $4 D$. Hasil dari penelitian ini mendefinisikan sifat $4 D$ sebagai ruang $3 D$ majemuk yang dapat berubah isi secara berkesinambungan. Penelitian ini dapat memperkaya pemahaman kita akan pengalaman ruang.
\end{abstract}

Kata kunci: Lingkungan maya, ruang empat dimensi, sistem pengontrol 


\section{INTRODUCTION}

\section{Research objectives}

Virtual space has been created as an extension to the physical space, to make possible the spatial functions that could not exist in the physical space. Researches of virtual architectural space design are still not common and the environments of it are still evolving. Most of the space designs are limited by implementing the spatial conception from the physical environment.

One of the possibilities from the virtual space that this research has found is the higher dimensional aspect of space that could be used beyond the 3D. The geometrical 4D method has been used in this research opposed to the concept of time as the 4th dimension, and it is expected to produce a new conception of space that will enrich our understanding in experiencing space.

The general objectives of this research was to find a suitable conception and method for planning and designing a virtual space for the designer and better experience in perceiving a virtual architectural space for the user. The fundamental aspect research was carried out to identify the effectiveness and defining the structure of $4 \mathrm{D}$ space.

\section{Related Researches}

Most researches about virtual architecture such as Doesinger (2008) mostly defines the cyberspace as the new landscape of designing an architecture, and computer generated forms as its spatial element. The similarity to this research is to find an architectural concept in the virtual space, but the spatial expression and experience are still limited to the 3D space.

Researches of 4D space by McMorgan Douglas (2008) showed the use of higher dimension to create structural ideas for the physical architecture while $4 \mathrm{D}$ concept application is used for computer graphic. Researches by Hollasch (1991) and Banchoff (1996) are known as a main understanding of defining the geometrical four-dimensional space.

Those researches have clarified four-dimensional space in the mathematical term, and did not define it as an architectural space. This paper uses the geometrical method above, and is successfully applied in the virtual architectural term, which makes this paper's originality value.

\section{METHOD}

\section{Research Flow}

The scope and objective of this paper is to propose and clarify the feasibility of architectural space in a 4D virtual environment and validation of the proposed space by developing a controller system.

Figure 1 shows the outline of the research flow. To begin with, an analogy of physical architecture is use to define the spatial requirements (1-a). Simultaneously, a controller system is developed in order to construct a basic 4D environment (1-b). The constructed $4 \mathrm{D}$ environment is furthermore analyzed in order to find the spatial volumetric value through its boundaries and the spatial origin where the user should locate (2). As a synthesis, the 4D spatial perception can be identified (3). Finally, the identification of architectural functions is performed by examining the 
exterior and interior characteristics (4). For the conclusion of this paper, an illustration of the virtual 4D architectural spaces is provided.

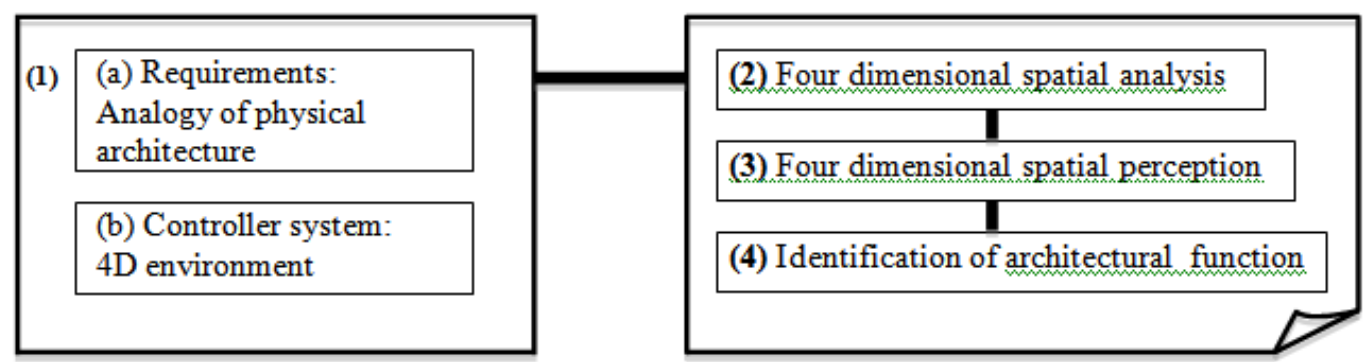

Figure 1. Research flow.

\section{Analogy of Physical Architecture}

Generally, the concept of architecture physically is considered to have three basic elements (environment, boundaries, and human). These elements correlate to each other to make the idea of architecture. Therefore, they are used as an analogy to define the virtual 4D architecture.

The analogy is: "Human performs his activities in a certain environment that are sheltered by boundaries to support and give comforts to those activities. Those boundaries have to be created suitably to the environment and the human activities in order to create proper architecture". From this analogy, the characteristic similarities of the physical architectural features are translated in virtual term. Figure 2 below shows the characteristics of the physical architecture (left) and virtual architecture (right).
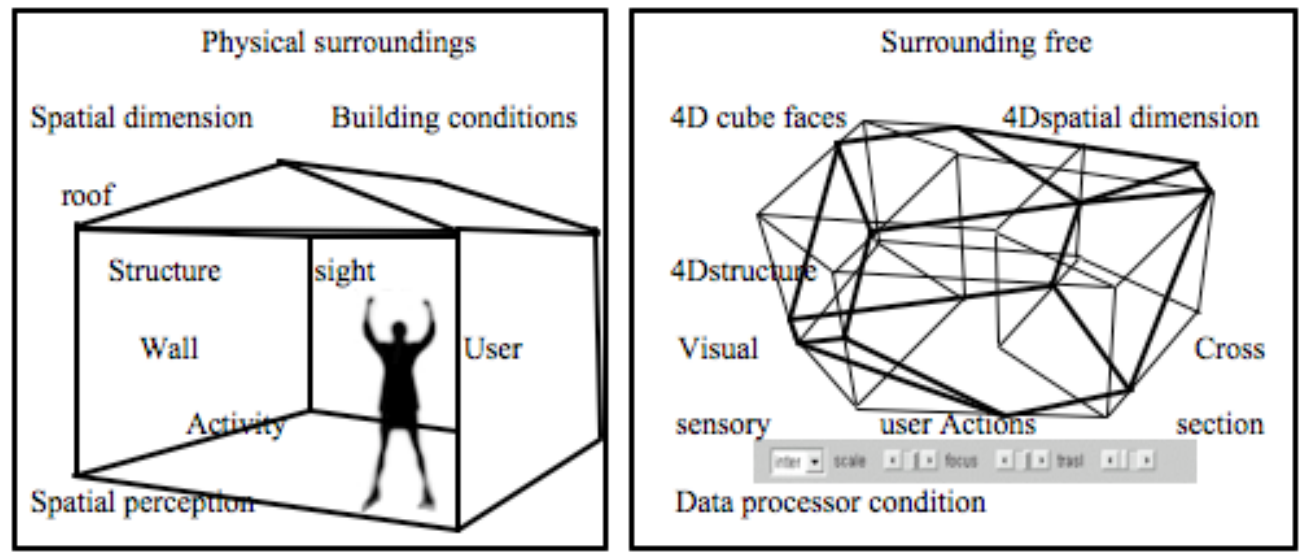

Figure 2. Physical architecture to virtual architecture.

By examining the comparison of the above features, the possibilities of the virtual 4D architecture are found in Figure 3. The possibilities that can be found as a result from the analogy are:

Element of environment is considered as the circumstance to be taken into consideration from the existing environment. Explicitly, a higher spatial dimension should be applied to extend the spatial functions of physical dimension (1). Lack of physical surroundings in virtual architecture should be considered as an advantage of creating self-determining spaces or user oriented spaces (2). The 
condition of the data processor can be considered as the system development and specifications for creating the space (3).

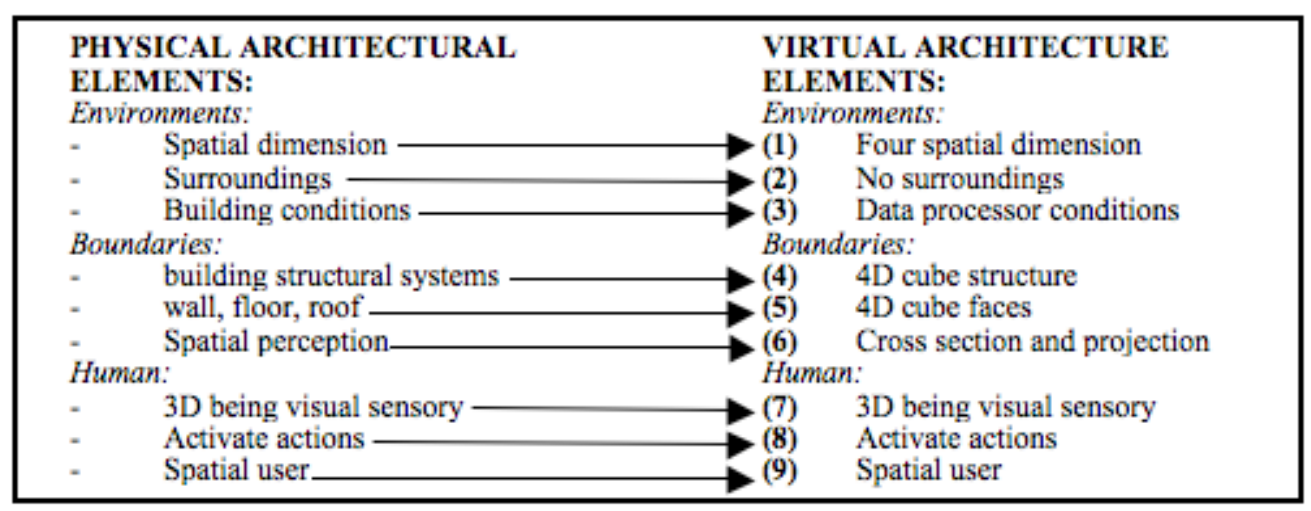

Figure 3. Physical contextual analogy to find virtual architectural requirements.

Element of boundaries is considered as the spatial volumetric value of four-dimensional space. The 4D cube structure (McMullen, 2008) is generated as the basic structure for the proposed space (4). The faces of the $4 \mathrm{D}$ cube are the analogy of spatial edge in physical context (5). Spatial perception for the human participant is limited to 3D space, for this reason the virtual 4D space have to intersect in 3D space (cross section) in order to be able to have a 3D spatial projection (6) (Abbott, 1992).

Element of human is considered as the 3D oriented spatial reference for the proposed space. Equivalent to the physical space as the 3D sensory is the consideration base for creating spatial features (7). Participant will activate action that results the spatial orientation to change, or to control the spatial features (8). Man as the spatial user will decide the architectural function of the proposed space, therefore the spatial function should be oriented to man's space requirements.

\section{Controller System}

A controller system has been developed as a tool to simulate the 4D spatial volume, to examine every part of the visible and hidden spaces, and to control multiple spaces by rotating and translating through the fourth axis. Figure 4 shows the class diagram of the system. The controller system is developed as a Java Applet for the reason of further network based development in order for any participant to be able to use the system on any browsers that supports Java.

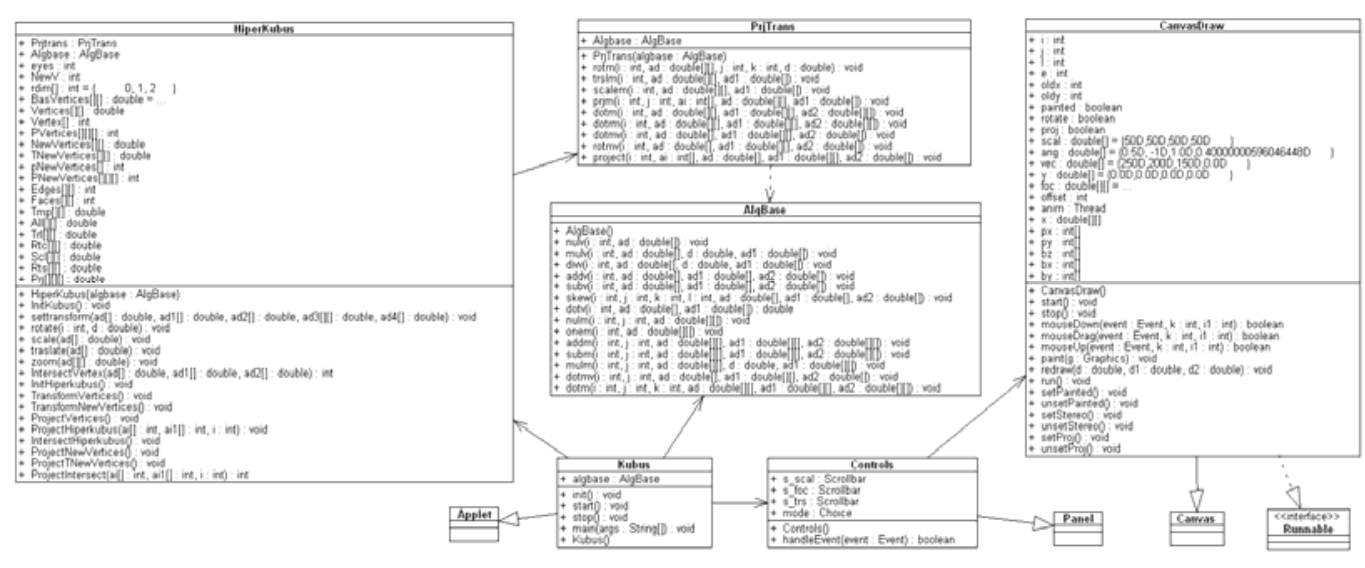

Figure 4. Diagram of the class controller. 
The first approach in developing the system is to establish the coordinates of the vertices. From the AlgBase class (Fig. 4) a 2-bit binary counter counting from 0 to 3 generates the sequence of bit (00) (01) (10) (11), by replacing the zero with -1 could obtain $(-1,-1)(-1,1)(1,-1)(1,1)$ that are the coordinates of the vertices of a quadrate of $4 \mathrm{D}$ cube located at the origin with its all sides parallel to the $\mathrm{X}$ and $\mathrm{Y}$ axis.

The next approach is to connect such vertices in correct mode and to make a transformational projection. The PrjTrans class is the group of the segments that have origin from a vertice and finish on the side's midpoint to the vertice point.

The applet executes two visual types of 4D space (projection and intersection). For the projection type the ProjectHiperkubus method of HiperKubus class is provided to generate a fourdimensional vision with a common mode, which looks small when it is far and vice versa. Applying a perspective to the higher dimensional-point coordinates, when they are far in the 4D space, they may construct smaller sides. For the intersection type the IntersectHiperkubus method of Hiperkubus class is provided to observe the intersection result between a 4D cube and a XYZ space. Finally, by inheriting from Panel class, the Controls class has applied the scroll bars and choice mode control for the applet.

From the CanvasDraw class, the runnable interface of mouse $\mathrm{X},-\mathrm{Y}$ rotation events and final projection has been applied. Figure 5 shows the screenshot from the generated wireframe model from the controller system.

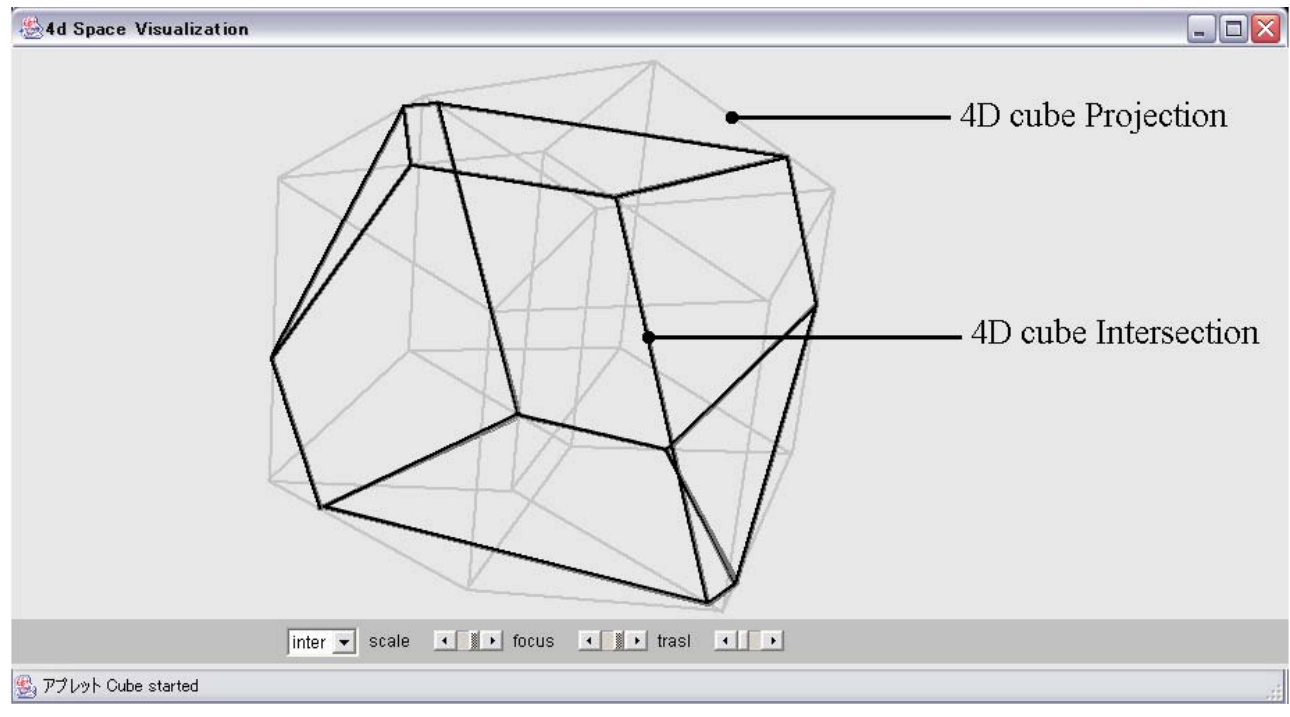

Figure 5. Controller system screenshot.

\section{RESULTS AND DISCUSSION}

\section{D Spatial Analysis}

The spatial volumetric value of the 4D space is found by analyzing the spatial boundaries and the where the user should locate in the 4D space, and shall use the term "spatial origin".

By examining from the generated wireframe model using the projection view, the spatial structure (boundaries (B1-B8)) from the generated 4D wireframe can be identified. The spatial 
boundaries that have formed the 4D space are eight 3D cubes constructed perpendicularly to the 3D cube in 4D spaces (Figure 6 B1-B8).
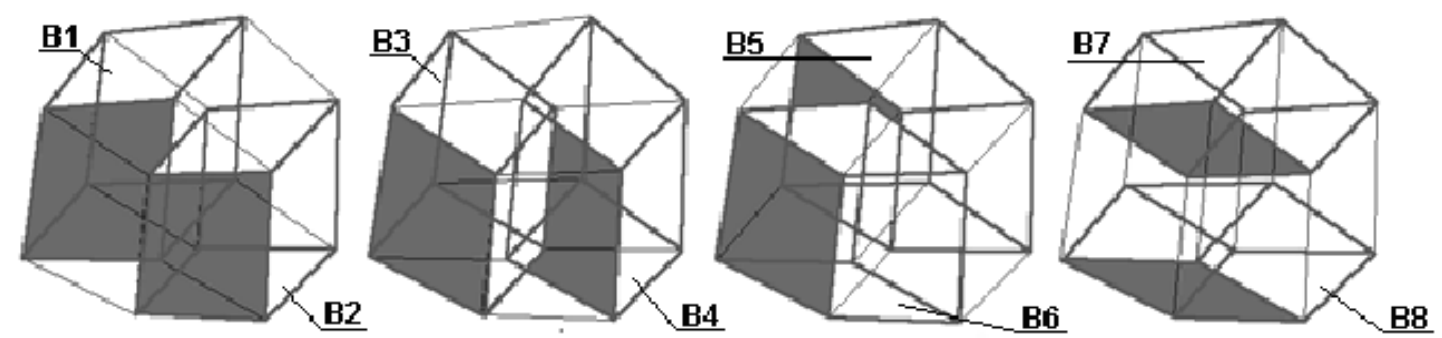

Figure 6. Four-dimensional cube boundaries.

The intersection of $4 \mathrm{D}$ space is a $3 \mathrm{D}$ space. In this intersection space (spatial origin) the human participant is possible to perceive the volumetric value of $4 \mathrm{D}$ space. This means that the participant will identify the 4D space as sequential 3D spaces.

Operating the mouse drag feature consequently will rotate the intersected space (S) in the $4^{\text {th }}$ dimension axis (V-axis). Figure 7 shows the variable 3D spaces (S1-S4) that constantly changes according to the interval of the $\mathrm{V}$ axis rotation.

S1

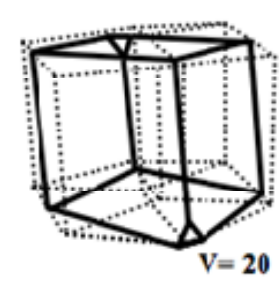

S2

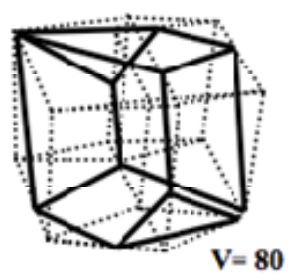

S3

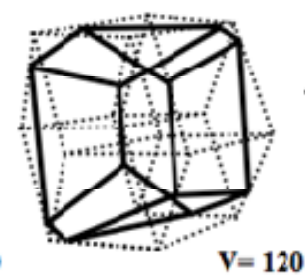

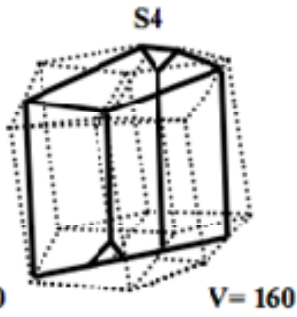

Figure 7. The visualization of 4D cube in 3D space.

\section{D Spatial Perception}

By combining the above analyzed spatial structure and spatial origin, the spatial definition of 4D space can be define as visible space and hidden spaces.

The visible spaces is the 3D spatial origin with six cubes as its boundaries that are perceivable as $3 \mathrm{D}$ space and functions as the main space for the participant.

Meanwhile, the hidden spaces are two of the eight boundaries of 4D cube that are hidden in the $4^{\text {th }}$ axis of $4 \mathrm{D}$ cube. To make appear these hidden spaces, the participant has to control or moves to the $4^{\text {th }}$ axis. Figure 8 shows the spatial condition at a certain translational movement of the visible space (S1) and hidden space (B1-B6).

\section{Identification of architectural functions}

Human perceives an architectural space in the physical environment as an exterior space and interior space. By operating the translation and rotation control, the participant will perceive the spatial 
volumetric expression of four-dimensional architecture as a fluid form that constantly changes to reveal its hidden spaces and functions. In this case participants can orient themselves to the space to suit their own purpose and needs of space.
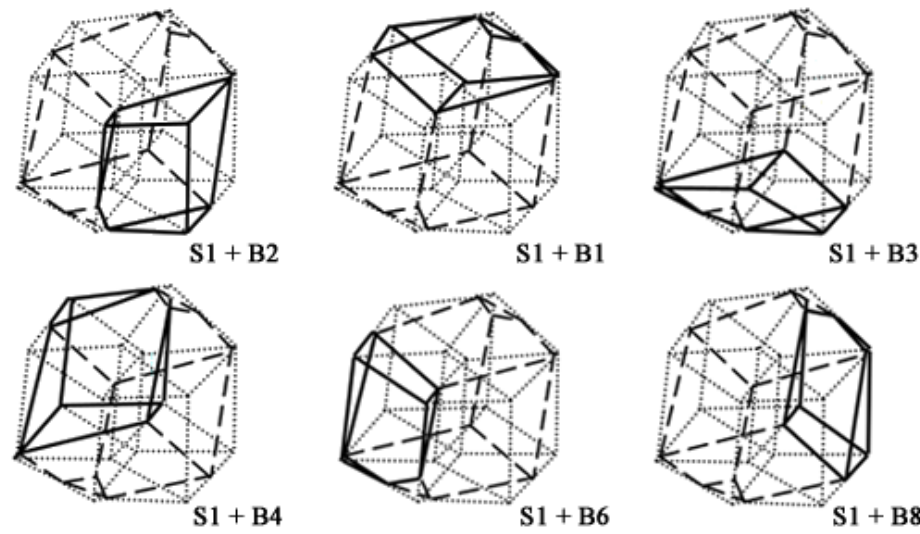

Figure 8. (S1) represents the visible space and (B1-B6) represents the 4D spatial boundaries.

\section{Exterior}

Through examining the controlling system, the effectiveness of the four-dimensional volume as an architectural space has been defined. By using the hidden line removal (the process of eliminating from the graphic display, lines that are obscured from view in a 2D representation of a 3D object), the spatial representation from the 4D intersection is defined as the exterior. The surfaces from this process can be perceived as the exterior boundaries. Altering surfaces that emerge from operating the rotation control (Figure 9 - Rv) represents another function of different exterior space (M7).

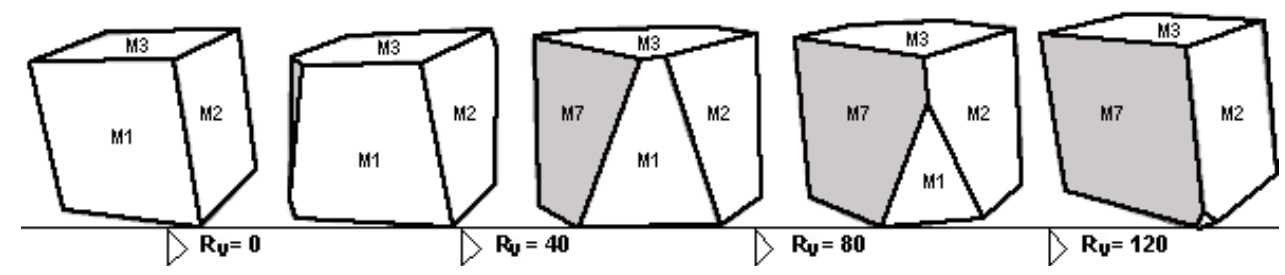

Figure 9. Exterior sequence from the rotation sequence

By operating the translation controller (Figure 10 - Tv) makes the exterior appear and disappear. The expression of an exterior form by applying this method is the spatial form that constantly changes to reveal its inner space and functions.

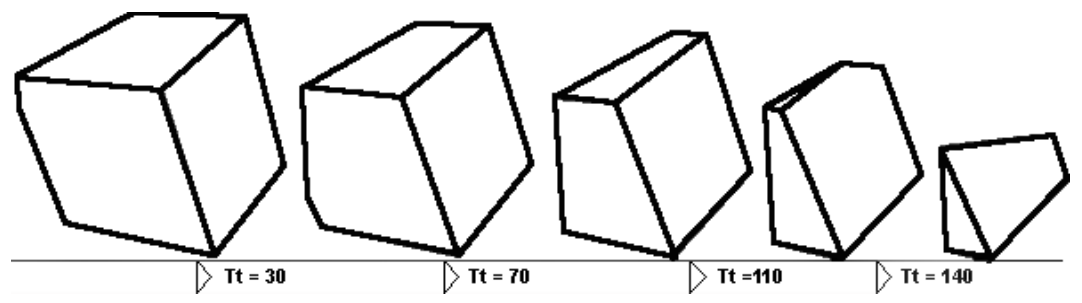

Figure 10. Exterior sequence from the translation control. 


\section{Interior}

The permutation of visible space and hidden space from the result of the 4D intersection and 4D projection views, without hidden line removal process, is defined as the interior space. In this condition the participant will see the boundaries that appear as three-dimensional volumes. Figure 11 shows the shifting spatial volume of a 4D interior space according to the rotational movement interval (Rv) from the controller system. The boundaries will also shift accordingly and open up other different boundaries (B7) that are also an association to another interior space.
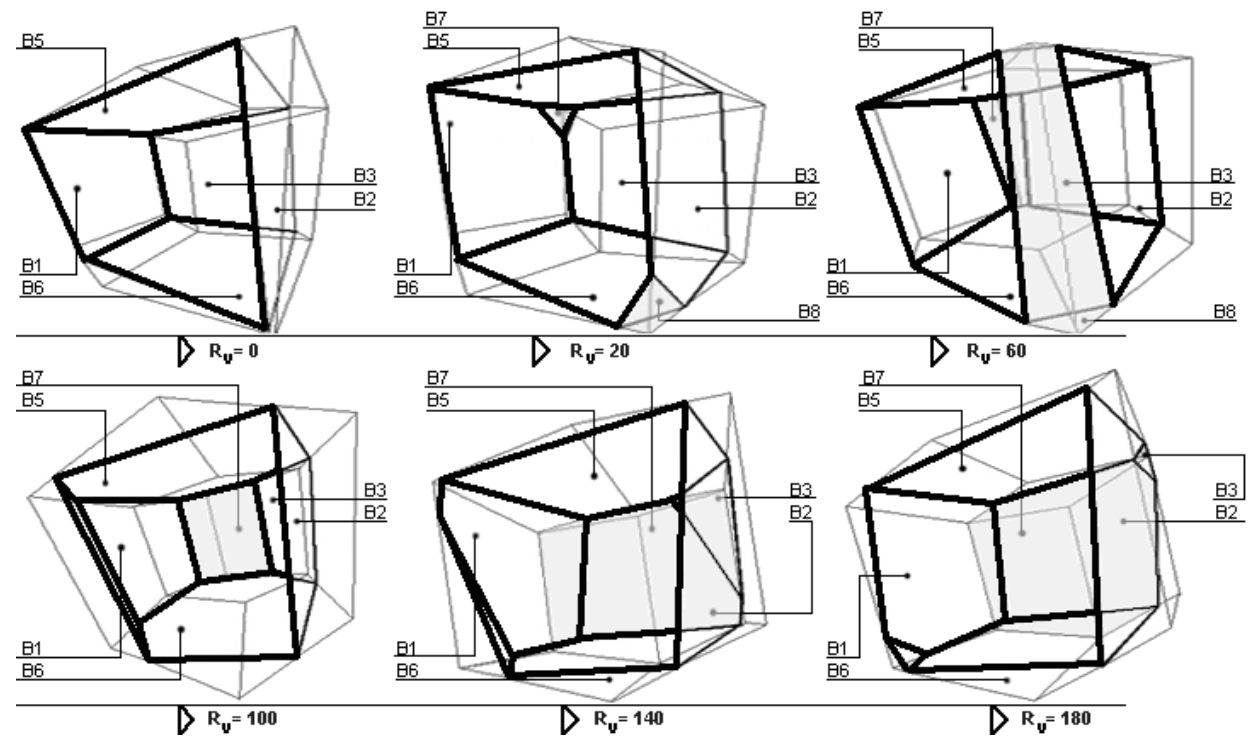

Figure 11. Interior sequence from rotation control.

Figure 12 shows the shifting spatial volume of a 4D interior space according to the translational movement interval (Tv). In this case, the spatial volume will shrink and disappear, consequently the B7 boundary will grow and transform as another interior space.

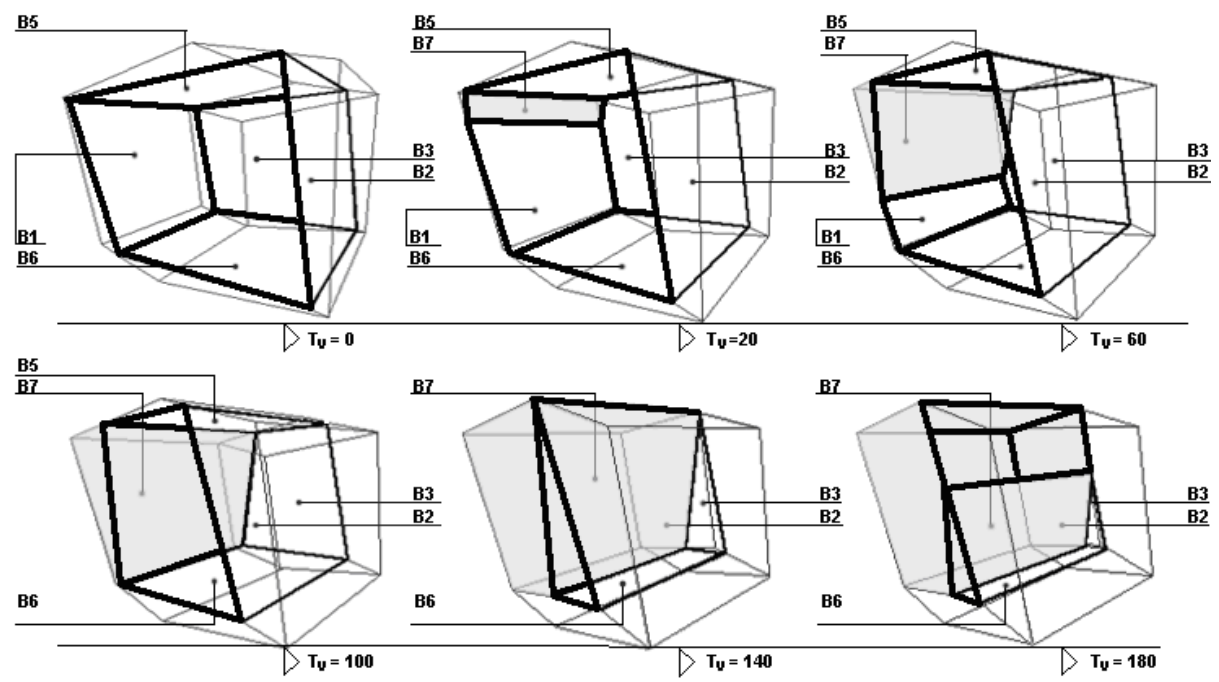

Figure 12. Interior sequence from translation control. 


\section{CONCLUSION}

This research explores the possibility of a virtual architectural space to exist in 4D environment, and enhances our understanding of an architectural space. This research also offers an alternative to create better architecture in virtual environment. The existing virtual architectural space derived from the physical environment that results a solid, linear, 3D conception of space has been improved to the idea of a fluid, nonlinear, 4D conception of space.

From the evaluation of exterior and interior spaces using rotation and translation controller, the usefulness of 4D spatial method for virtual architectural functions has demonstrated. In this way, the idea of creating architectural space in a virtual environment has been improved and enhanced from the presently existing idea.

\section{Illustration}

The visualization of the spatial design for the virtual exhibition space has shown the estimation result of controlling the fourth axis of movement (Figure 13). For the purpose of spatial function, this virtual exhibition space is classified in three types of functions: the atrium, archive, gallery spaces.. Figure 13.1 shows that rotating around the $\mathrm{V}$ axis will fluidly change the orientation of the exterior function of the main spaces (Atrium, Archive, Gallery). Figure 13.2 shows that operating the translation movement along the $\mathrm{V}$ axis will reveal the hidden sub-spaces from one of the main space, in this case the gallery space, and furthermore hide the sub spaces as the slider passes through the main space. Figure 13.3 shows the visualization of the interior space where the walls proceed toward the viewer and shifts a complex but graceful transformational movements.
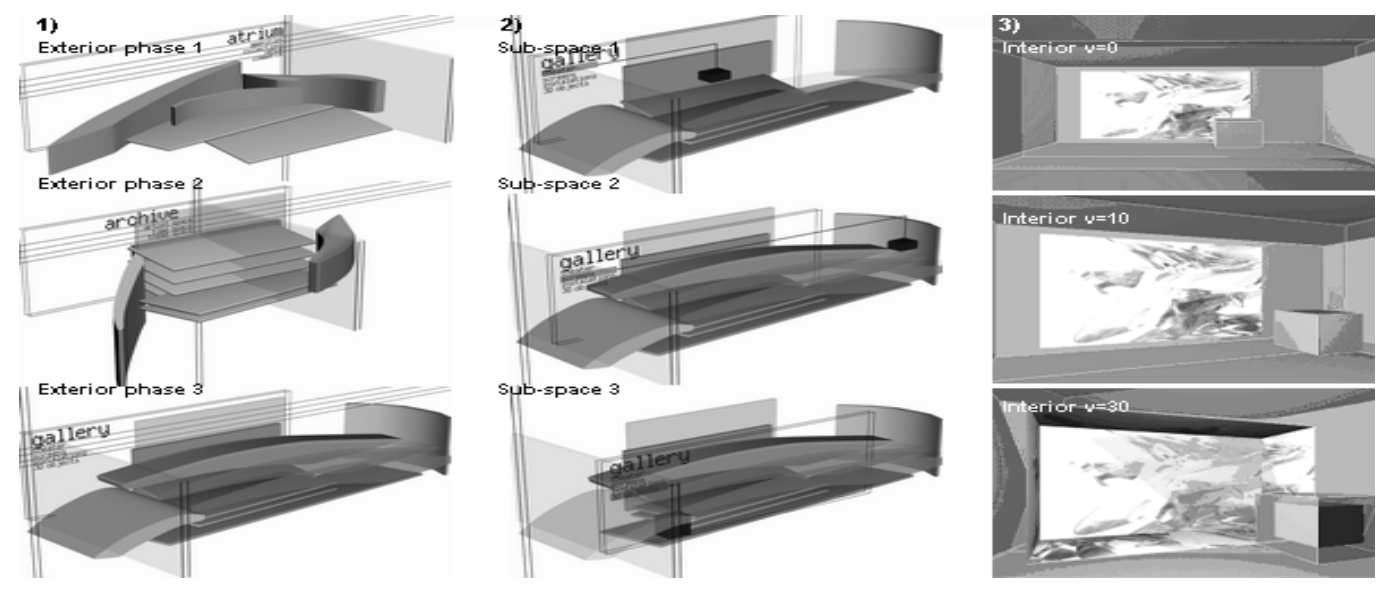

Figure 13. 4D Virtual exhibition space illustration.

\section{REFERENCES}

Abbott, Edwin A. (1992). Flatland: A Romance of Many Dimensions. New York: Dover Publications.

Banchoff, Thomas F. (1996). Methods of Examining 4D Object in the 3D Space. Beyond the Third Dimension: Geometry, Computer Graphics, and Higher Dimensions. New York: Scientific American Library. 
Chris, McMullen. (2008). The Visual Guide To Extra Dimensions: Visualizing the Fourth Dimension, Higher-Dimensional Polytopes, and Curved Hypersurfaces. California: CreateSpace.

Hollasch, Steven Richard. (1991). Four-Space Visualization of 4D Objects. Arizona: Arizona State University.

Kaatryn, MacMorgan-Douglas (2008). The Circle, Cubed: Erecting the Temple in Four Dimensions. New York: Covenstead Press.

Stephan, Doesinger. (2008). Space Between People: How the Virtual Changes Physical Architecture. New York: Prestel Publishing. 